\title{
MOLECULAR DETECTION OF TOXOPLASMA GONDII DNA IN RAW GOAT AND SHEEP MILK WITH DISCUSSION OF ITS PUBLIC HEALTH IMPORTANCE IN ASSIUT GOVERNORATE
}

\author{
O.A. SADEK ${ }^{*}$; ZEINAB M. ABDEL-HAMEED* and HUDA M. KURAA** \\ ${ }^{*}$ Animal Health Research Institute, Assiut Provincial Lab, Food Hygiene Department \\ ** Animal Health Research Institute, Assiut Provincial Lab, Parasitology Department
}

Assiut University Email: www.aun.edu.eg

Received at: 31/3/2015

Accepted: 11/5/2015
This study was carried out to investigate the incidence of Toxoplasma gondii in 105 sheep and goat raw milk samples in Assiut, Egypt. Milk samples were tested by microscopic examination, Latex agglutination test and 50 samples were tested with PCR assay. The incidence of Toxoplasma gondii in sheep and goat milk samples was $10.48 \%$ (11/105) by microscopic examination, 39\% (41/105) by Latex agglutination test and 16\% (8/50) by PCR assay. High significant differences were recorded in incidence of Toxoplasma in raw sheep milk in $8.62 \%(5 / 58)$ by micropscopic examination, in $39.66 \%(23 / 58)$ ) by latex agglutination test and detection of B1 gene of Toxoplasma gondii in $10.71 \%$ (3/28) by PCR assay. While, significance differences were found in incidence of Toxoplasma in raw goat milk in $12.77 \%(6 / 47))$ by microscopical examination, in $38.30 \%(18 / 47)$ by Latex agglutination test in addition to detection of B1 gene of Toxoplasma gondii in $22.73 \%(5 / 22)$ by PCR assay. The results showed that sheep and goats were excreting Toxoplasma gondii DNA in their milk. The results of this study revealed that Latex agglutination test and PCR assay could become useful tools to diagnose the incidence of Toxoplasma gondii in sheep and goat milk samples. This study is the first report of direct detection of Toxoplasma gondii in sheep and goat milk samples in Assiut Governorate, Egypt. Control measures and public heath importance were also discussed in this study.

Key words: Toxoplasma gondii DNA antibodies caprine ovine milk Assiut Governorate.

\section{INTRODUCTION}

Milk is raised as a complete food, especially for children and seniors as it has a high value for proteins, minerals, fats and vitamins. Milk from goats is more easily digested than cow's milk by children as ingestion of raw goat milk remains a common practice in the rural areas in Egypt, particularly among poor children and those that are allergic to cows' milk. Therefore, the hygienic quality of milk has a high importance from the public health point of view but sometimes Toxoplasma infection may occur.

Toxoplasmosis has priority as one of five parasitic diseases with public health action [Center for Disease Control and Prevention (CDC), 2013]. Toxoplasma gondii is an obligate intracellular protozoan that infects humans and a wide range of warm-blooded animals (Smith and Reduck, 2000). All mammals including man act as intermediate hosts who infected by ingestion of sporulated oocysts, cyst-contaminated meat, milk contaminated by tachyzoites or transplacentarily, except feline species which acts as a definitive host (Innes, 1997; Pepin et al., 1997 and Jenum and Stray-Pedersen, 1998).

Toxoplasma gondii is one of the important zoonotic parasites of world-wide, based on geographic location; $15-85 \%$ of the human population is asymptomatically infected with Toxoplasma gondii. Up to one third of the human population in the world was chronically infected with toxoplasmosis. Sheep and goats were well known sources of human infection with toxoplasmosis among food animals. Drinking of unpasteurized goat milk was considered source of human infections (Aspinall et al., 2002; Acha and Szyfres, 2003; Reischl et al., 2003; Lehmann et al., 2006; Havelaar et al., 2007; Pappas et al., 2009; Dubey, 2010; Al-Khatib, 2011; Dubey et al., 2011 and Mancianti et al., 2013).

Sheep and goat are more widely and most seriously affected by Toxoplasma gondii among livestock animals and show high seroprevalences in many areas of the world, up to 92 and $75 \%$, respectively. Adult 
goats were reported to have died from acute toxoplasmosis and this disease is a common cause of abortion, early embryonic death with resorption or mummification, stillbirth and neonatal death in sheep and goats. Polymerase chain reaction method was used for detection of Toxoplasma gondii DNA in the milk based on its B1 gene (Buxton, 1998; Dunn et al., 1999; Tenter et al., 2000; Petersen et al., 2001; Dubey, 2004; Buxton et al., 2007; Dubey, 2009a; Tenter, 2009; Ragozo et al., 2010; Asgari et al., 2011 and Tavassoli et al., 2013).

Toxoplasmosis causes significant reproductive and economic losses in animals as well as public health concerns as consumption of contaminated milk damage the human health and can facilitate zoonotic transmission. The presence of a recent or active infection of animals could be an important source of transmission of the infection to men. Animals shed Toxoplasma gondii tachyzoites in all body fluids, including milk in the acute stage of the disease. Moreover, Toxoplasma gondii being reported to be more prevalent in goat milk than in their meat (Jittapalapong et al., 2005 and Prelezov et al., 2008; Camossi et al., 2011 and Luptakova et al., 2015).

Toxoplasmosis has a major public health importance in food safety issue as its tachyzoite has been found in unpasteurized milk of sheep and goats. Consumption of unpasteurized goat's milk has been associated with human toxoplasmosis, therefore, it is advisable that milk should be boiled or pasteurized before human consumption as these procedures will inevitably kill any potentially present tachyzoites (Tenter et al., 2000; Hiramoto et al., 2001; Ertug et al., 2005; Jones et al., 2009; Inpankaew et al., 2010; Bezerra et al., 2013; Dehkordi et al., 2013; Flatt and Shetty, 2013; Mancianti et al., 2013; Dubey and Jones 2014; Dubey et al., 2014 and Da Silva et al., 2015). Clinical toxoplasmosis in human has been attributed to drinking of unpasteurized goat's milk due to release of Toxoplasma tachyzoites in naturally infected goats milk (Sacks et al., 1982; Chiari and Neves, 1984 and Skinner et al., 1990) and was linked to toxoplasmosis in an infant (Riemann et al., 1975 and Dubey and Lappin, 2006).

Abdel-Rahman et al. (2012) identified Toxoplasma specific antibodies in both serum and milk of naturally infected goats using IHAT. Moreover, Azab et al. (1992) and Haridy et al. (2010) detected Toxoplasma gondii specific antibodies in milk using IFAT and ELISA, respectively.

Ghoneim et al. (2009) recorded that drinking raw sheep or goat milk is one of the strongest risk factors of acquiring Toxoplasma gondii infection by high risk women at El-Fayoum, Egypt. Serological diagnosis represents the first and the most widely used approach to define the stage of toxoplasmosis. Diagnosis of infection in pregnancy can be improved by determination of Toxoplasma DNA. Also, (Balea et al., 2012) highlighted the potential risk of human infection with Toxoplasma gondii in Cluj Country by consumption of raw milk from small ruminants.

Human infections by Toxoplasma gondii are primarily asymptomatic but lymphadenopathy or ocular toxoplasmosis may occur in some patients. Toxoplasma gondii infection in pregnant women may lead to abortion, stillbirth or other serious consequences in newborns. The surviving infected infants suffer from progressive mental retardation, hydrocephalus or microcephalus, chorioretinitis and jaundice and neonatal death (Joynson and Wreghitt, 2001; Dubey, 2004; Montoya and Liesenfeld, 2004; Sharif et al., 2007; Tenter, 2009 and Higa et al., 2010). In immunocompromised patients, clinical toxoplasmosis ranges from asymptomatic reactivation to severe disseminated disease with encephalitis, meningoencephalitis or more commonly tumor lesions. Also, life-threatening cases of pneumonia have recently been described. Motor syndrome, consciousness disturbances, seizures and focal signs are common manifestations that are clinically indistinguishable from other CNS complications. A disseminated disease with detection of Toxoplasma in blood and bone marrow may occur. The reactivated disease may be fatal if not recognized and treated early (Mele et al., 2002; Schurmann et al., 2002 and Leal et al., 2007).

Pettersen (1984) showed that the transmission of Toxoplasma gondii tachyzoit in the milk was attributed to suckling trauma and tissue cyst excretion. While, Deyrup-Olsen and Luchtel (1998) described that excretion of Toxoplasma gondii tachyzoites in mammary gland is facilitated by cellular exocytosis of milk secretion. During prelactation, relatively stable mammary cells could harbor Toxoplasma gondii cysts. Therefore, those silent cysts could be secreted from the mammary gland cells by exocytosis then coated by host cell membranes similar to milk fat globules secretion allowing milk contamination inside the gland.

Although tachyzoites are sensitive to proteolytic enzymes and are destroyed by gastric digestion, it can be survived for up to two hours in acid pepsin solutions and that oral application of tachyzoites might have resulted in an infection (Dubey, 1998). However, infants who are more susceptible to toxoplasmosis than adults have a lower concentration of proteolytic enzymes in their gastrointestinal tract. This may explain one report of toxoplasmosis in a breast-fed infant whose mother acquired a primary infection with Toxoplasma gondii (Bonametti et al., 1997).

Asgari et al. (2011) demonstrated that Toxoplasma tachyzoites are resistant to milk media and conserve their infectivity for up to $30 \mathrm{~min}$ due to its oral 
transmission. Moreover, Walsh et al. (1999) indicated the survival of Toxoplasma tachyzoites in goat milk at $4^{\circ} \mathrm{C}$ for 3-7 days. Therefore, reinforcing the importance of milk pasteurization before any processing or ingestion. Infectivity of bradyzoite in milk was maintained even after storage for 20 days at refrigerator temperatures (Hiramoto et al., 2001).

Riemann et al. (1975); Räisänen (1978) and Sacks et al. (1982) reviewed that Toxoplasma gondii trophozoites survive and remain infectious for a long time in biological liquid media ( $24 \mathrm{~h}$ in saline, 3 days in $3.5 \%$ serum albumen, 3 days in colostrum, and 1743 days in serum solutions) and can easily penetrate mucous membranes, so can enter the host through mucosal tissue and thereby gain access to the host circulation or lymphatic system before reaching the stomach.

The present study aimed to investigate the incidence of Toxoplasma gondii infection in sheep and goats raw milk in Assiut, Egypt as an indication of the parasite excretion in milk and evaluation the possibility of using milk as a valid tool for the diagnosis of toxoplasmosis in small ruminants.

\section{MATERIALS and METHODS}

Collection of samples: A total of 105 milk samples were collected from 58 sheep and 47 goats randomly selected from various regions Aboteeg, Al-Qusiya, Al-Mateya in Assiut, Egypt. Milk samples were taken manually after disinfection of the teats with $70 \%$ ethyl alcohol and collected in clean dry and sterile test tubes. Samples were kept under refrigeration until arrival to the laboratory. Milk smears were prepared for microscopic examination and milk samples rapidly frozen at $-20^{\circ} \mathrm{C}$ until used for serological examination and PCR assay.

Preparation and staining of milk smear: Fresh milk samples centrifuged and milk smears were made from the cells deposited and clean slide. One drop of deposit of each centrifuged fresh milk samples was taken to slide and spread into an even thin film by a second clean slide held at a $45^{\circ}$ angle and immediately dried by the air. The slide was labeled and kept in upright position in a special box. The prepared microscopic smears were fixed by absolute methyl alcohol then allow drying. The films stained with freshly diluted Giemsa stain solution for 20 minutes. The films washed by distilled water to remove the excess of stain. The slide placed upright for draining and drying. Then the slides were thoroughly examined with microscope using oil immersion lens $(1000 \times)$ for presence of Toxoplasma tachyzoites (Duran-Jorda, 1944; Schalm et al., 1971 and Lindmark-Månsson et al., 2006).

Serological examination: Milk samples thawed at room temperature and centrifuged at $2000 \mathrm{rpm}$ for 20 minutes and the interface between the lipid layer and the pelleted cellular debris was used for detection of Toxoplasma gondii antibodies using undiluted milk (Grundy et al., 1983).

Latex agglutination test (Toxo Latex Kit, Cam Tech Medical, U. K.): Bring milk samples and reagents to room temperature and a serological pipette used to apply $40 \mu \mathrm{l}$ of milk samples to slide. The vial of latex agglutination was shaked well and added $20 \mu \mathrm{l}$ of toxo latex to the milk sample, then mixed well with stirring sticks and the slide rotated slowly. After 4-6 minutes the sample was checked for agglutination (Syamala et al., 2008).

Polymerase Chain Reaction (PCR): Milk samples from 50 (40 positive and 10 negative by latex agglutination test) were tested with PCR assay.

1. Extraction of DNA from 50 collected milk samples: Milk samples thawed at room temperature then centrifuged at $2200 \mathrm{rpm}$ for 5 minutes to be concentrated (Murphy et al., 2002). Further $1 \mathrm{ml}$ of the sediment was re-suspended in $200 \mu \mathrm{TE}(1 \mathrm{mM}$ EDTA, $10 \mathrm{mlM}$ Tris-HCl with $\mathrm{pH} 7.6$ and $300 \mu \mathrm{l}$ of $0.5 \mathrm{M}$ EDTA with $\mathrm{pH} 8.0$ ) and centrifuged at 3000 rpm for 10 minutes to avoid the interference with casein (Psifidi et al., 2010). Thus, the milk pullet was diluted in $200 \mu \mathrm{l}$ of PBS and the extraction of DNA was done by using Genomic DNA Purification Kit (Biotools, Madrid, Spain), according to the manufacturer instructions. After extraction, DNA was stored at $-20^{\circ} \mathrm{C}$ until use.

2. DNA amplification reaction: The extracted DNA was amplified by PCR into 35-fold repetitive B1 gene specified for the characterization of Toxoplasma gondii (Bezerra et al., 2013) using primers B1 gene (Biosearch Technologies, Inc., USA)

\section{Toxo B22 (F) 5'AACGGGCGAGTAGCACCTGAGGAG'3} Toxo B23 (R) 5'TGGGTCTACGTCGATGGCATGACAAC'3

with 115 bp (Bretagne et al., 1993). The reaction was applied in $20 \mu \mathrm{l}$ reaction volume containing $10 \mu \mathrm{l}$ of $2 \mathrm{x}$ power Dream Tag Green PCR master mix, $20 \mu \mathrm{l}$ pmol $\mathrm{B} 1$ each primer and $2 \mu \mathrm{l}$ of the purified DNA.

3. The reaction conditions of PCR: The reaction conditions consisted of one cycle of $95^{\circ} \mathrm{C}$ for 5 minutes followed by 40 cycles of $94^{\circ} \mathrm{C}$ for 30 seconds, $60^{\circ} \mathrm{C}$ for 30 seconds, $72^{\circ} \mathrm{C}$ for 1 minute and the final extension at $72^{\circ} \mathrm{C}$ for 10 minutes (Master cycler, Eppendorf, Hamburg, Germany). The agarose gel was prepared from agarose powder $\left(\right.$ Bioshop ${ }^{\mathrm{R}}$, Canada inc. lot No: OE16323) in concentration $2 \%$ in 1x TBE (89 mM Tris-Borate, 2 mM EDTA at pH 8.3) and run in $1 \mathrm{x}$ TBE, $5 \mu \mathrm{M}$ ethidium bromide (Bioshop ( Canada Inc, Lot No: 0A14667). The amplification products were analyzed by $1.2 \%$ of agarose gel electrophoresis stained with ethidium bromide. PCR 
product was electrophoresed at 45 minutes at 100 volts and examined using UV transilluminator and photography. 100 bp DNA ladder (Fermentas, lot No: 00052518) was used as a marker.

Statistical analysis: The resulting data were analyzed using SPSS (2007) for Windows (SPSS, version 16, Inc., Chicago, IL). Chi-square was performed, differences were considered significant at values of $\mathrm{P}<0.05$

\section{RESULTS}

A total of 105 sheep and goat milk samples were tested by microscopic examination, Latex agglutination test and 50 samples (40 positive and 10 negative by Latex agglutination test) were tested with PCR. Incidence of Toxoplasma gondii in sheep and goat milk samples was $10.48 \%(11 / 105)$ by microscopic examination and $39 \%(41 / 105)$ by Latex agglutination test. Positive Toxoplasma gondii DNA were detected in $16 \%$ (8/50) sheep and goat's milk samples (Table 3).
Incidence of Toxoplasma had high significant differences in raw sheep milk samples between micropscopic examination, latex agglutination test and PCR assay. Microscopic examination of milk smears stained with Giemsa stain showed banana shape tachyzoites of Toxoplasma gondii (Figure 2, 3, 4). Incidence of Toxoplasma gondii in raw sheep milk samples was $8.62 \%(5 / 58))$ by microscopic examination and $39.66 \%(23 / 58)$ by Latex agglutination test (Table 1). The B1 gene of Toxoplasma gondii was detected by PCR in 3 sheep milk samples (Figure 7,8 ). The results showed that $10.71 \%(3 / 28)$ of sheep were excreting Toxoplasma gondii DNA in their milk (Table 1). While, significance differences were found in incidence of Toxoplasma in raw goat milk by micropscopic examination, Latex agglutination test and PCR assay. Incidence of Toxoplasma gondii in raw goat milk samples was $12.77 \%(6 / 47)$ by microscopic examination and $38.30 \%(18 / 47))$ by Latex agglutination test (Figure 1). The B1 gene of Toxoplasma gondii was detected by PCR in 5 goat milk samples (Figure 5, 6). The results showed that $22.73 \%$ (5/22) goats were excreting $T$. gondii DNA in their milk (Table 2).

Table 1: Incidence of Toxoplasma gondii in raw sheep milk samples based on microscopic examination, Latex agglutination test and PCR assay.

\begin{tabular}{|c|c|c|c|c|c|}
\hline \multirow{3}{*}{ Used test } & \multirow{3}{*}{$\begin{array}{c}\text { Number of } \\
\text { examined samples }\end{array}$} & \multicolumn{4}{|c|}{ Result } \\
\hline & & \multicolumn{2}{|c|}{ Positive } & \multicolumn{2}{|c|}{ Negative } \\
\hline & & No. & $\%$ & No. & $\%$ \\
\hline Microscopic examination & 58 & 5 & $8.62^{* * *}$ & 53 & 91.38 \\
\hline Latex agglutination & 58 & 23 & $39.66^{* *}$ & 35 & 60.34 \\
\hline Polymerase chain reaction (PCR) & 28 & 3 & $10.71^{* *}$ & 25 & 89.29 \\
\hline
\end{tabular}

** Means high significance differences $\left(\chi^{2}=18.94\right.$ and $\left.\mathrm{P}<0.01\right)$.

Table 2: Incidence of Toxoplasma gondii in raw goat milk samples based on microscopic examination, Latex agglutination test and PCR assay.

\begin{tabular}{cccccc}
\hline \multirow{2}{*}{ Used test } & \multirow{2}{*}{$\begin{array}{c}\text { Number of } \\
\text { examined samples }\end{array}$} & \multicolumn{2}{c}{ Positive } & \multicolumn{2}{c}{ Negative } \\
\cline { 3 - 6 } & & & $\%$ & No. & $\%$ \\
\hline Microscopic examination & 47 & 6 & $12.77^{*}$ & 41 & 87.23 \\
\hline Latex agglutination & 47 & 18 & $38.30^{*}$ & 29 & 61.70 \\
\hline Polymerase chain reaction (PCR) & 22 & 5 & $22.73^{*}$ & 17 & 77.27 \\
\hline
\end{tabular}

* Means significance differences $\left(\chi^{2}=8.245\right.$ and $\left.\mathrm{P}<0.05\right)$.

Table 3: Comparison of microscopic examination, Latex agglutination test and Polymerase chain reaction (PCR) for detecting Toxoplasma in sheep and goat milk samples.

\begin{tabular}{cccc}
\hline Detection methods & Number & Positive samples & Incidence (\%) \\
\hline Microscopic examination & 105 & 11 & $10.48 \%$ \\
\hline Latex agglutination test & 105 & 41 & $39 \%$ \\
\hline Polymerase chain reaction (PCR) & 50 & 8 & $16 \%$ \\
\hline
\end{tabular}




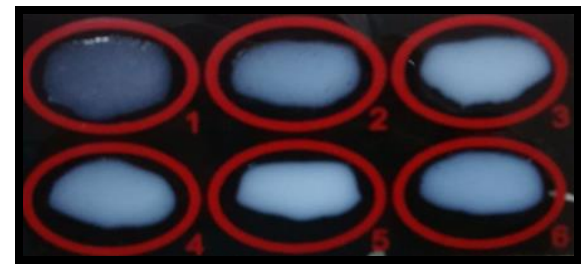

Figure (1): Showing latex agglutination test of Toxoplasma gondii with positive agglutination in well (1) while wells $(2,3,4,5,6)$ were negative milk samples.

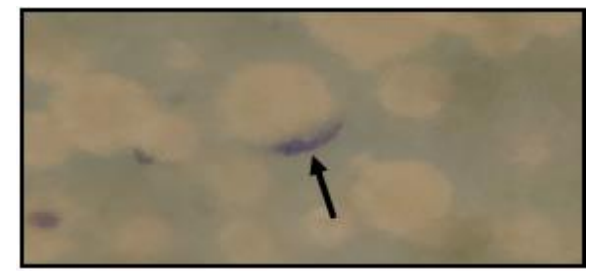

Figure (3): Showing banana shape Toxoplasma gondii tachyzoite (arrow) in sheep milk smear stained with giemsa stain (Lens, 1000x).

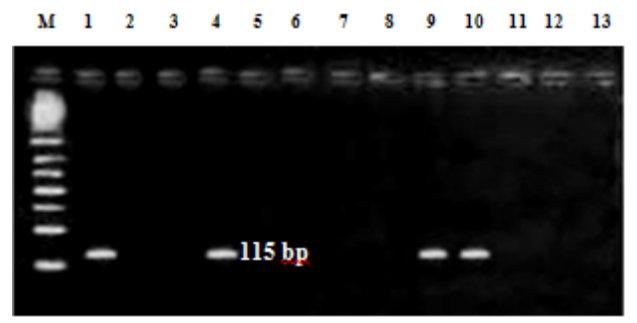

Figure (5): The electrophoresis pattern of PCR amplicon on goat milk samples using B1 gene of Toxoplasma gondii primer (115 bp PCR product). M: 100 bp DNA ladder; 1: Control positive; 2: Control negative; 4, 9 and 10: Positive samples for Toxoplasma gondii; 3, 5, 6, 7, 8, 11, 12 and 13: Negative samples.

$\begin{array}{lllllllllllllll}\text { M } & 1 & 2 & 3 & 4 & 5 & 6 & 7 & 8 & 9 & 10 & 11 & 12 & 13 & 14\end{array}$

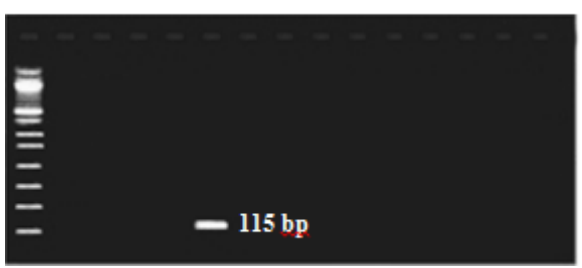

Figure (7): The electrophoresis pattern of PCR amplicon on sheep milk samples using B1 gene of T. gondii primer (115 bp PCR product). M: $100 \mathrm{bp}$ DNA ladder; 5: Positive samples for Toxoplasma gondii; 1, 2, 3, 4, 6, 7, 8, 9, 10,11, 12, 13 and 14: Negative samples.

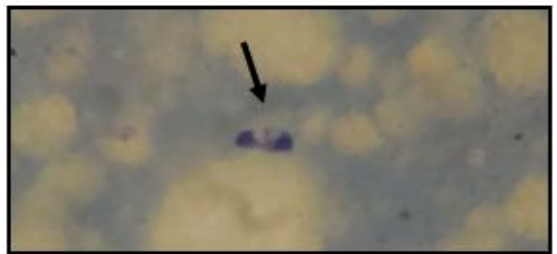

Figure (2): Showing banana shape Toxoplasma gondii tachyzoite (arrow) in sheep milk smear stained with giemsa stain (Lens, 1000x).

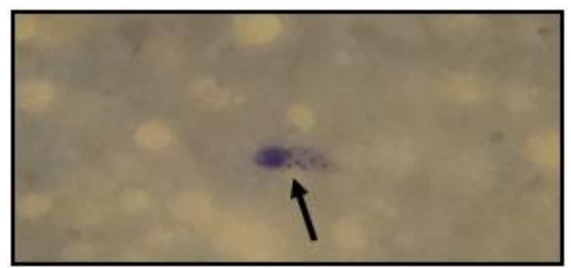

Figure (4): Showing banana shape Toxoplasma gondii tachyzoite (arrow) in goat milk smear stained with giemsa stain (Lens, 1000x).

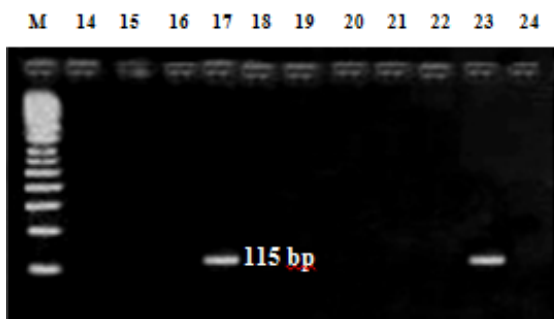

Figure (6): The electrophoresis pattern of PCR amplicon on goat milk samples using B1 gene of Toxoplasma gondii primer (115 bp PCR product). M: 100 bp DNA ladder; 17 and 23: Positive samples for Toxoplasma gondii; 14, 15, 16, 18, 19, 20, 21, 22 and 24: Negative samples.

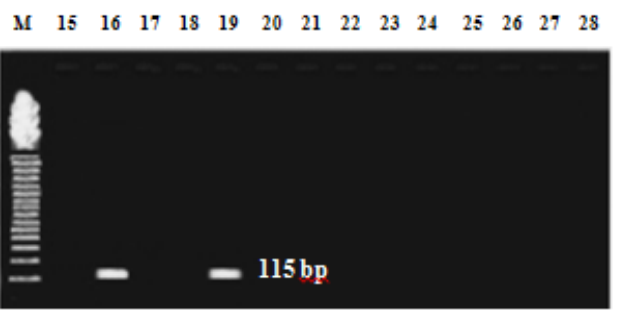

Figure (8): The electrophoresis pattern of PCR amplicon on sheep milk samples using B1 gene of $T$. gondii primer (115 bp PCR product). M: $100 \mathrm{bp}$ DNA ladder; 16 and 19: Positive samples for Toxoplasma gondii ; 15, 17, 18, 20, 21, 22, 23, 24, 25, 26, 27and 28: Negative samples. 


\section{DISCUSSION}

Ghoneim et al. (2009) and Abdel-Rahman et al. (2012) recorded high prevalence of Toxoplasma gondii infection in sheep and goats in Egypt due to wide spread of large number of infected stray cats which is in favor of a higher prevalence of oocysts in humid environment and farming animal rearing are also common. Egyptian rural areas have the habit of eating homemade cheese (Kareish cheese) which is made from raw milk. Such habit has a relation to Toxoplasma gondii (El Deeb et al., 2012). In addition, (Fusco et al., 2007) showed that local homemade cheese from raw milk is considered a risk factor for public health.

Toxoplasmosis plays an important role in public health worldwide particularly in rural areas that use unpasteurized milk. Contamination of milk with Toxoplasma gondii could be originated from the infected animal or contamination of milk with cats' feces due to presence of stray cats around and within farms. Cats are the important risk factor for Toxoplasma gondii infection in small ruminants (Chiari et al., 1987; Cordeiro, 2006; Jittapalapong et al., 2008 and Bezerra et al., 2013). Toxoplasma oocysts shed continuously in the cat's feces from 4 until 14 days after infection with an expected peak output of tens of millions at 6-8 days. Thus, fifty grams of infected cat feces may contain as many as 10 million oocysts (Dubey and Frenkel, 1972). Infected cats shed Toxoplasma gondii oocysts that after sporulation become infective for men and animals, preserving this capability for up to 18 months in the environment (Gorbani et al., 1983).

In the present study, the incidence of Toxoplasma gondii in sheep and goat milk samples was $10.48 \%$ by microscopic examination, 39\% \% by Latex agglutination test and $16 \%$ by PCR assay (Table 3 ). The differences observed could be due to the diagnostic technique or breeding condition and management. The high incidence of Toxoplasma gondii infection indicated continuous exposure of sheep and goats to infection due to heavy environmental contamination with oocysts shed form the observed stray cats in the farms with poor management conditions (Masala et al., 2003).

Caprine toxoplasmosis was reported worldwide (Dubey, 1980; Masala et al., 2003 and Dubey, 2009b). Toxoplasma antibodies are detectable two weeks post infection and maintain in the host a low level through all life (Lin and Bowman, 1991). Serum antibodies was recorded in an endemic area indicating past or present invasive disease while presence of antibodies in milk indicate present or recent infection which reflect local antigenic stimuli to infection, such antibody detection may help in studies of the endemicity of the disease (Grundy et al., 1983).
Testing of milk samples is easier and less expensive than testing of blood samples (Schares et al., 2004) and can be considered a good diagnostic tool for toxoplasmosis at flock level. The level of antibodies in milk is in general lower than that in serum (Elvander et al., 1995). Toxoplasma antibodies were detected in the milk of naturally infected lactating women (Azab et al., 1992).

Incidence of Toxoplasma gondii in sheep and goat milk samples was $39 \%(41 / 105)$ by Latex agglutination test. Sheep milk samples showed higher percent of anti-Toxoplasma IgG (39.66\%) than goats milk samples $(38.30 \%)$ (Table 1,2$)$. Lower infection rates in goats compared to those in sheep may be attributed to the differences in susceptibility to Toxoplasma gondii and the feeding habits of the animals (Bahrieni et al., 2008).

In this study, incidence of Toxoplasma gondii antibodies was $38.30 \%$ in goat milk samples by Latex agglutination test (Table 2). In comparison to our results, higher result was recorded by (Abdel-Rahman et al., 2012) who found that $58.90 \%$ of the examined goats milk samples in Egypt had Toxoplasma gondii antibodies. While, lower results were reported by Dehkordi et al. (2013) who recorded that the prevalence Toxoplasma gondii antibodies was $8.88 \%$ in caprine milk samples by ELISA test in Iran and (Da Silva et al., 2015) who estimated that antiToxoplasma gondii IgG antibodies was $5.78 \%$ in raw goat milk samples by IFAT in Brazil. The variation in these results may be attributed to the difference in the diagnostic technique used, study locality, breeding conditions and management (Masala et al., 2003).

Abdel-Rahman et al. (2012) found Toxoplasma gondii tachyzoites in the milk of both chronically and acutely infected goats. They explained the presence of Toxoplasma gondii tachyzoites in the milk of chronically infected goats was due to the resurgence of tissue Toxoplasma gondii tachyzoites cysts which can circulate again and be excreted in the milk during physiological decrease in the peripartum immunity.

The obtained results revealed that the incidence of Toxoplasma gondii antibodies by Latex agglutination test in sheep milk samples was (39.66\%) (Table 1). Lower results were observed by Dehkordi et al. (2013) who showed that the prevalence Toxoplasma gondii was $5.94 \%$ in ovine milk samples by ELISA test in Iran and (Da Silva et al., 2015) who found anti-Toxoplasma gondii IgG antibodies in raw milk of sheep was $3.76 \%$ by the IFAT in Brazil. It worth to mention that, our climate favors the survival of oocysts and has contributed to high Toxoplasma prevalence (Ciamak, 2006).

PCR assay is a major breakthrough for the diagnosis of Toxoplasma gondii infection and have higher 
accuracy, sensitivity and specificity than traditional diagnostic methods (Held et al., 2000; Martins et al., 2000 and Kompalic-Cristo et al., 2007). Several PCR assays have been developed for the detection of Toxoplasma gondii DNA by amplification of target as $\mathrm{B} 1$ gene which is a 35 -fold repetitive gene sequence; PCR amplifying this gene target has shown high specificity for Toxoplasma gondii DNA detection (Jones et al., 2000 and Reischl et al., 2003).

Powell et al. (2001) recorded lactational transmission of Toxoplasma gondii from experimentally infected cats to their kittens since the organism detected in feline milk by either bioassay or PCR. While (Costa and Langoni, 2010) confirmed the presence of tachyzoites of Toxoplasma gondii in the milk secreted from experimentally infected rats by PCR as well as the seroconversion of offspring after breastfeeding, both in chronic and acute infections with intermittent parasite elimination, corroborating the results of Pettersen (1984). Also, Dehkordi et al. (2013) showed higher sensitivity of PCR for detection Toxoplasma gondii DNA from milk samples in Iran.

Data presented showed that Toxoplasma gondii DNA was detected in $22.73 \%(5 / 22)$ of goat milk samples by PCR assay (Table 2). This result is in agreement with that pointed out by Ghoneim et al. (2009) who recorded Toxoplasma genomic DNA in $25 \%$ of goats in El-Fayoum Governorate, Egypt. Unlike the obtained result, lower results were estimated by Dehkordi et al. (2013) and Tavassoli et al. (2013) who found that Toxoplasma gondii DNA was $9.44 \%$ and $1.07 \%$ of goats milk samples by PCR in Iran, respectively, (Bezerra et al., 2013 and Da Silva et al., 2015) who detected DNA of Toxoplasma gondii in 6.05 and $2.7 \%$ of the raw goat milk samples by PCR technique in Brazil, respectively, (Mancianti et al., 2013) who documented that prevalence of Toxoplasma gondii DNA was found in $13 \%$ of milk samples naturally infected in Italy and Ahmed et al. (2014) who estimated that Toxoplasma gondii DNA was $8 \%$ of goat from rural settings at Sharkia, Egypt. While, higher prevalence was recorded by Spišák et al. (2010) who found that the presence of Toxoplasma gondii DNA was $32.56 \%$ in goats milk from a farm in Slovakia. The variation in these results may be attributed to the immune status of animals, timing of infection and genetic composition of the host and the organism (Suzuki, 2000).

Moreover, the results of this research showed that Toxoplasma gondii DNA was detected in $10.71 \%$ (3/28) of sheep milk samples by PCR assay (Table1). Lower results were indicated by Fusco et al. (2007) who found that the prevalence of Toxoplasma gondii DNA was $(3.4 \%)$ by PCR in ovine milk samples from Italy, (Camossi et al., 2011) who identified Toxoplasma gondii DNA in the milk of naturally infected ewes in 5\% milk samples by PCR in Brazil,
(Tavassoli et al., 2013 and Dehkordi et al., 2013) who recorded Toxoplasma gondii DNA was 4.63 and $6.48 \%$ of sheep milk samples by polymerase chain reaction (PCR) in Iran, respectively and (Ahmed et $a l$., 2014) who found that $2 \%$ of sheep milk samples had Toxoplasma gondii DNA in the rural settings at Sharkia, Egypt. This variation may be due to the difference in the study locality, management and distribution and behavior of cats (Buxton, 1990 and Tenter et al., 2000). On the other hand, higher results were found by Ghoneim et al. (2009) who detected Toxoplasma genomic DNA in $67.7 \%$ of sheep in ElFayoum and Luptakova et al. (2015) who found Toxoplasma gondii DNA in ewes' milk samples with real-time PCR was $28 \%$. This variation may be attributed to frequency of felines on farms and climatic variations from one region to another (Dubey, 2004).

In the present study, serological results do not coincide with the PCR results because not all serologically positive animals eliminate the parasite in their milk. Several milk samples positive serologically revealed negative PCR results. This elimination depends on the animal infection phase and their immunity. This in agreement with Bezerra et al. (2013) and Camossi et al. (2011) who noticed that compromised immunity in sheep during the peripartum period may favour the reactivation of cystic forms of Toxoplasma gondii, thus eliminating tachyzoite in milk.

The obtained results revealed that 2 goat milk samples were positive in PCR and negative by Latex agglutination test. These results may be due to that animals were in the initial phase of the infection, in which the quantity of antibodies is not yet sufficient to be detected by serological tests. These biological characteristics could explain the prevalence of animals that were positive in the PCR and negative in the serology (Bezerra et al., 2013).

Furthermore, the present work showed that sheep and goats were excreting Toxoplasma gondii DNA in their milk as first recording in Assiut Governorate, Egypt. These results are in agreement with Spišák et al. (2010) and Tavassoli et al. (2013) who demonstrated that presence of Toxoplasma gondii DNA in milk of sheep and goats refers to the risk of human infection through consumption raw milk. Also, Ahmed et al. (2014) showed a significant correlation between the seroprevalence of Toxoplasma gondii in pregnant women and the contact with cats and consumption of raw milk and homemade cheese at Sharkia, Egypt.

\section{CONCLUSION}

From the obtained results, it was concluded that there is high incidence of toxoplasmosis among sheep and 
goat milk samples in Assiut Governorate, Egypt. Presence of Toxoplasma gondii DNA in the milk of sheep and goats raises the possibility that the parasite could be transmitted to human through consumption of raw milk. From the result achieved, it can suggest that boiling or pasteurization of milk before human consumption to eliminate the risk of parasite transmission to milk consumers. Moreover, further investigations are necessary to detect the incidence of Toxoplasma gondii DNA in other milk-producing animals and apply effective control strategies against toxoplasmosis.

\section{ACKNOWLEDGMENT}

Grateful thanks to Dr. Heba M. M. Kuraa, Veterinarian in Assiut Veterinary District, Egypt, for her help during the performance of the practical part.

\section{REFERENCES}

Abdel-Rahman, M.A.M.; EL-Manyawe, S.M.; Khateib, A.M. and Saba, S. (2012): "Occurrence of Toxoplasma antibodies in caprine milk and serum in EGYPT." Assiut Vet. Med. J., 58 (133): 145-152.

Acha, P.N. and Szyfres, B. "Eds." (2003): Zoonoses and Communicable Diseases Common to Man and Animals." $3^{\text {rd }^{\mathbf{d}^{*}}}$ ed., Washington: Pan American Health Organization. 416 p.

Ahmed, H.A.; Shafik, S.M.; Ali, M.E.M.; Elghamry, S.T. and Ahmed, A.A. (2014): "Molecular detection of Toxoplasma gondii DNA in milk and risk factors analysis of seroprevalence in pregnant women at Sharkia, Egypt." Veterinary World 7 (8): 594-600.

Al-Khatib, R.M. (2011): "Serological Studies of Toxoplasma gondii infection in camels (Camelus dromedarius)." Assiut Vet. Med. J. 57 (130): 223-232.

Asgari, Q.; Mehrabani, D.; Motazedian, M.H.; Kalantari, M.; Nouroozi, J. and Adnani Sadati, S.J. (2011): "The viability and infectivity of Toxoplasma gondii tachyzoites in dairy products undergoing food processing." Asian J. Animal Sci. 5 (3): 202-207.

Aspinall, T.V.; Marlee, D.; Hyde, J.E. and Sims, P.F.G. (2002):" Prevalence of Toxoplasma gondii in commercial meat products as monitored by polymerase chain reaction-Food for thought?" Int. J. Parasitol. 32: 1193-1199.

Azab, M.E.; Kamel, A.M.; Makled, K.M.; Khattab, H.; El Zayyat, E.A.; Abo Amer, E.A. and Samy, G. (1992): "Naturally occurring Toxoplasma antibodies in serum and milk of lactating women." J. Egyptian Society Parasitol. 22 (2): 561-568.
Bahrieni, M.; Fasihi Harandi, M.; Beigzadeh, M.; Kamyabi, H. and Zia-Ali, N. (2008): "Risk factors analysis associated with seropositivity to Toxoplasma gondii in sheep and goats in southeastern Iran using modified agglutination test (MAT)." Iran. J. Parasitol.; 3(1): 38-43.

Balea, A.; Paştiu, A.I.; Györke, A.; Mircean, V. and Cozma, V. (2012): "The dynamics of antiToxoplasma gondii antibodies (IgG) in small ruminants and pigs from Cluj Country, Romania" Sci. Parasitol. 13(4): 163-168.

Bezerra, M.J.; Kim, P.C.; Moraes, É.P.; Sá, S.G.; Albuquerque, P.P.; Silva, J.G.; Alves, B.H. and Mota, R.A. (2013): "Detection of Toxoplasma gondii in the milk of naturally infected goats in the Northeast of Brazil." Transboundary and Emerging Diseases (C) 2013 Blackwell Verlag GmbH: 1- 4.

Bonametti, A.M.; Passos, J.N.; Da Silva, E.M.K. and Macedo, Z.S. (1997): $\quad$ "Probable transmission of acute toxoplasmosis through breast feeding." J. Trop. Pediatr.;43(2): 116.

Bretagne, S.; Costa, J.; Vidaud, M.; Nhieu, J. and Feith, J. (1993): "Detection of Toxoplasma gondii by competitive DNA amplification of bronchoalveolar lavage samples." J. Infect. Dis. 168 (6): 1585-1588.

Buxton, D. (1990): "Ovine toxoplasmosis: a review." J. Royal Society Med. 83: 509-511.

Buxton, D. (1998): "Epidemiology and economic impact of toxoplasmosis in animal production: In Proceedings of the Cost-820 Annual Workshop, Vaccines against Animal Coccidioses." Tecni Publication España, SL, Madrid, pp.: 52-53.

Buxton, D.; Maley, S.W.; Wright, S.E.; Rodger, S.; Bartley, P. and Innes, $E$ A. (2007): "Toxoplasma gondii and ovine toxoplasmosis: new aspects of an old story." Vet. Parasitol. 149 (1-2): 25-8.

Camossi, L.G.; Greca-Júnior, H.; Corrêa, A.P.; Richini-Pereira, V.B.; Silva, R. C.; Da Silva, A.V. and Langoni, H. (2011): "Detection of Toxoplasma gondii DNA in the milk of naturally infected ewes." Veterinary Parasitology 11; 177 (3-4): 256-261.

Center for Disease Control and Prevention (CDC) (2013): "Parasites - Toxoplasmosis (Toxoplasma infection)," Available at http://www.CDC.gov/parasites/npi.html (accessed 10.01.2013).

Chiari, C.A. and Neves, D.P. (1984): "Toxoplasmose humana adquirida através da ingestão de leite de cabra." Memórias do Instituto Oswaldo Cruz; 79 (3): 337-340.

Chiari, C.A.; Lima, W.S.; Antures, C.M.F.; and Lima, J.D. (1987): "Sero-epidemiologia da toxoplasmose caprina em Minas Gerais, Brasil." Arquivo Brasileiro de Medicina Veterinaria e Zootecnia, 39, 587-609. 
Ciamak, G. (2006): "Serological survey of antibodies to Toxoplasma gondii." Afr. J. Health Sci. 13 (1-2): 131-134.

Cordeiro, P.R.C. (2006): "Mercado de leite de cabras e seus derivados." Rev. Cons. Fed. Med. Vet. $8,1-8$.

Costa, V.M. and Langoni, H. (2010): "Detection of Toxoplasma gondii in the milk of experimentally infected Wistar female rats." J. Venom. Anim. Toxins incl. Trop. Dis. 16 (2): 368-374.

Da Silva, J.G.; Alves, B.H.; Melo, R.P.; Kim, P.C.; Neto, O.L.; Bezerra, M.J.; Sá, S.G. and Mota, R.A. (2015): "Occurrence of anti-Toxoplasma gondii antibodies and parasite DNA in raw milk of sheep and goats of local breeds reared in Northeastern Brazil." Acta Trop. 142: 145-148.

Dehkordi, F.S.; Rahimi, E. and Abdizadeh, R. (2013): "Detection of Toxoplasma gondii in raw caprine, ovine, buffalo, bovine, and camel milk using cell cultivation, cat bioassay, capture ELISA and PCR methods in Iran." Foodborne Pathogens and Disease; 10 (2): 120-125.

Deyrup-Olsen, I. and Luchtel, D.L. (1998): "Secretion of mucous granules and other membrane-bound structures: a look beyond exocytosis." Int. Rev. Cytol., 183: 95-141.

Dubey, J.P. (1980): "Persistence of encysted Toxoplasma gondii in caprine livers and public health significance of toxoplasmosis in goats." J. Am. Vet. Med. Assoc. 177 (12): 1203-1207.

Dubey, J.P. (1998): "Re-examination of resistance of Toxoplasma gondii tachyzoites and bradyzoites to pepsin and trypsin digestion." Parasitology 116, 43-50.

Dubey, J.P. (2004): "Toxoplasmosis-a waterborne zoonosis." Vet. Parasitol. 126 (1-2): 57-72.

Dubey, J.P. (2009a): "Toxoplasmosis in sheep-the last 20 years." Vet. Parasitol. 7; 163(1-2): $1-14$.

Dubey, J.P. (2009b): "Toxoplasmosis of Animals and Humans." 2nd ed. USA, Florida: CRC Press, Inc. Boca Raton.

Dubey, J.P. (2010): "Toxoplasmosis of animals and humans." 2nd ed. Boca Raton, Florida: CRC Press:1-313.

Dubey, J.P. and Frenkel, J.K. (1972): "Cyst-induced toxoplasmosis in cats." J. Protozool.19: 155177.

Dubey, J.P. and Jones, J.L. (2014): "Comments on "Detection of Toxoplasma gondii in raw caprine, ovine, bovine, and camel milk using cell cultivation, cat bioassay, capture ELISA, and PCR methods in Iran". Foodborne Pathogens and Disease 11 (6): 500-501.

Dubey, J.P. Lappin, M.R. (2006): "Toxoplasmosis and neosporosis. In: Greene CE, Editor.
Infectious diseases of the dog and cat. " $3 \mathrm{rd}$ ed. St. Louis: Saunders/Elsevier, pp.: 754-775.

Dubey, J.P.; Rajendran, C.; Ferreira, L.R.; Martins, J.; Kwok, O.C.; Hill, D.E.; Viluylena, I.; Zhou, H.; Su, C. and Jones, J.L. (2011): "High prevalence and genotypes of Toxoplasma gondii isolated from goats, from a retail meat store, destined for human consumption in the USA.” Int. J. Parasitol. 41 (8): 827-833.

Dubey, J.P.; Verma, S.K.; Ferreira, L.R.; Oliveira, S.; Cassinelli, A.B.; Ying, Y.; Kwok, O.C. H.; Tuo, W.; Chiesa, O.A.; Jones, J.L. (2014): "Detection and survival of Toxoplasma gondii in milk and cheese from experimentally infected goats." J. Food Prot. 10 (7): 17471753.

Dunn, D.; Wallon, M.; Peyron, F.; Petersen, E.; Peckham, C. and Gilbert, R. (1999): "Motherto-child transmission of toxoplasmosis: risk estimates for clinical counseling or risk estimates for clinical decision-making." Lancet 53: $1829-1833$

Duran-Jorda, F. (1944): "The smithsonian/NASA astrophysics data system cell contents of milk." Nature, Volume 154, Issue 3918, pp.: 704-705.

El Deeb, H.K.; Salah-Eldin, H.; Khodeer, S. and Allah, A.A. (2012): "Prevalence of Toxoplasma gondii infection in antenatal population in Menoufia Governorate, Egypt." Acta Trop. 124 (3): 185-191.

Elvander, M.; Edwards, S.; Näslund, K. and Linde, N. (1995): "Evaluation and application of an indirect ELISA for the detection of antibodies to bovine respiratory syncytial virus in milk, bulk milk, and serum." Vet. Diagn. Invest. 7 (2): 177-182.

Ertug, S.; Okyay P.; Turkmen, M. and Yuksel, H. (2005): "Seroprevalence and risk factors for Toxoplasma infection among pregnant women in Aydin province, Turkey." BMC Public Health 5: 66-66.

Flatt, A. and Shetty, N. (2013): "Seroprevalence and risk factors for toxoplasmosis among antenatal women in London: a re-examination of risk in an ethnically diverse population." Eur. J. Public Health 23(4): 648-652.

Fusco, G.; Rinaldi, L.; Guarino, A.; Proroga, Y.T.; Pesce, A. Giuseppina, D.M. and Cringoli, G. (2007): "Toxoplasma gondii in sheep from the Campania region (Italy)." Vet. Parasit. 149 (34): 271-274.

Ghoneim, N.H.; Shalaby, S.I.; Hassanain, N.A.; Zeedan, G.S.G.; Soliman, Y.A. and Abdalhamed, A.M. (2009): "Detection of genomic Toxoplasma gondii DNA and antitoxoplasma antibodies in high risk women and contact animals." Global Veterinaria 3 (5): 395-400. 
Gorbani, M.; A. Hafizi, M.T.; Shegerfcar, M.; Rezaeian, A.; Nadim, M.; Anwar and Afshar, A. (1983): "Animal toxoplasmosis in Iran. J. Trop. Med. and Hyg. 86, 73-76.

Grundy, M.S.; Cartwright-Taylor, L.; Lundin, L.; Thors, C. and Huldt, G. (1983): "Antibodies against Entamoeba histolytica in human milk and serum in kenya." J. Clin. Microbiol. 17(5): 753-758.

Haridy F.M.; Saleh, N.M.; Khalil, H.H. and Morsy, T.A. (2010): "Anti- Toxoplasma gondii antibodies in working donkeys and donkey's milk in greater Cairo, Egypt." J. Egypt. Soc. Parasitol. 40(2): 459 - 464.

Havelaar, A.H.; Kemmeren, J.M. and Kortbeek, L.M. (2007): "Disease burden of congenital toxoplasmosis." Clin. Infect. Dis. 44(11): 1467-1474.

Held, T.K.; Krüger, D.; Switala, A.R.; Beyer, J.; Kingreen, D.; Busemann, C.; Janitschke, K. and Siegert, W. (2000): "Diagnosis of toxoplasmosis in bone marrow transplant recipients: Comparison of PCR based results and immunohistochemistry." Bone Marrow Transplant. 25: 1257-1262.

Higa, L.T.; Araujo, S.M.; Tsuneto, L.; CastilhoPelloso, M.; Garcia, J.L.; Santana, R.G.; and Falavigna-Guilherme, A.L. (2010): "A prospective study of Toxoplasma-positive pregnant women in Southern Brazil: A health alert. Trans. R. Soc." Trop. Med. Hyg., 104: 400-405.

Hiramoto, R.M. ; Mayrbaurl-Borges, M.; Galisteo, Jr.A.J.; Meireles, L.R.; Macre, M.S. and Andrade, Jr.H.F. (2001): "Infectivity of cysts of the ME-49 Toxoplasma gondii strain in bovine milk and homemade cheese," Revista de Saúde Pública 35(2): 113-118.

Innes, E.A. (1997): "Toxoplasmosis: Comparative species susceptibility and host immune response ." Comp .Immunol. Microbiol. Infect. Dis. 20: 131-138.

Inpankaew, T.; Pinyopanuwut, N.; Chimnoi, W.; Kengradomkit, C. and Sununta, C. (2010): "Serodiagnosis of Toxoplasma gondii infection in dairy cows in Thailand." Transbound. Emerg. Dis. 57: 42-45.

Jenum, P.A. and Stray-Pedersen, B. (1998): "Development of specific immunoglobulins G, $\mathrm{M}$ and A following primary Toxoplasma gondii infection in pregnant women." J. Clin. Microbiol. 36: 2907-2913.

Jittapalapong, S.; Sangvaranond, A.; Pinyopanuwat, N.; Chimnoi, W.; Khachaeram, W.; Koizumi S. and Maruyama S. (2005): "Seroprevalence of Toxoplasma gondii infection in domestic goats in Satun Province, Thailand." Vet. Parasitol. 127(1): 17-22.

Jittapalapong, S.; Sangwaranond, A.; Inpankaew, T.; Phasuk, C.; Pinyopanuwat, N.; Chimnoi, W.;
Kengradomkij, C.; Arunwipat, $P$. and Maruyama, S. (2008): "Seroprevalence of Toxoplasma gondii infection in dairy cows in northeastern Thailand." Southeast Asian J. Trop. Med. Public Health 39 (Suppl 1): 1-5.

Jones, C.D.; Okhravi, N.; Adamson, P.; Tasker, S. and Lightman, S. (2000): "Comparison of PCR detection methods for B1, P30, and 18S rDNA genes of Toxoplasma gondii in aqueous humor." Invest Ophthalmol. Vis. Sci. 41 (3): 634-644.

Jones, J.L.; Dargelas, V.; Roberts, J.; Press, C.; Remington, J.S. and Montoya, J.G. (2009): "Risk factors for Toxoplasma gondii infection in the United States." Clin. Infect. Dis. 49: 878-884.

Joynson, D.H.M. and Wreghitt, T. (2001): "Toxoplasmosis: A Comprehensive Clinical Guide." Cambridge University Press, Cambridge, pp.: 193-276.

Kompalic-Cristo, A.; Frotta, C.; Suárez-Mutis, M.; Fernandes, $O$. and Britto, C. (2007): "Evaluation of a real-time PCR assay based on the repetitive $\mathrm{B} 1$ gene for the detection of Toxoplasma gondii in human peripheral blood." Parasitol. Res. 101: 619-625.

Leal, F.E.; Cavazzana, C.L.; de Andrade, H.F.; Galisteo, A.J.; de Mendonça, J.S. and Kallas, E.G. (2007): "Toxoplasma gondii pneumonia in immunocompetent subjects: Case report and review." Clin. Inf. Dis. 44: 62-66.

Lehmann, T. Marcet, P.L. Graham, D.H. Dahl, E.R. and Dubey, J.P. (2006): "Globalization and the population structure of Toxoplasma gondii," Proceedings of the National Academy of Sciences of the United States of America 103 (30): 11423-11428.

Lin, D.S. and Bowman, D.D. (1991): "Cellular response of cats with primary toxoplasmosis." J. Parasitol. 77: 272-279.

Lindmark-Månsson, H.; Bränning, C.; Aldén, G. and Paulsson, M. (2006): "Relationship between somatic cell count, individual leukocyte populations and milk components in bovine udder quarter milk." Int. Dairy J. (16): 717-727.

Luptakova, L.; Benova, K.; Rencko, A. and Petrovova, E. (2015): "DNA detection of Toxoplasma gondii in sheep milk and blood samples in relation to phase of infection." Vet. Parasitol. 208 (3-4): 250-253.

Mancianti, F.; Nardoni, S.; D'Ascenzi, C.; Pedonese, F.; Mugnaini, L.; Franco, F. and Papini, R. (2013): "Seroprevalence, detection of DNA in blood and milk, and genotyping of Toxoplasma gondii in a goat population in Italy." BioMed Res. Int. 1-20.

Martins, T.B.; Hillyard, D.R.; Litwin, C.M.; Taggart, E.W.; Jaskowski, T.D. and Hill, H.R. (2000): "Evaluation of a PCR probe capture assay for 
the detection of Toxoplasma gondii." Am. J. Clin. Pathol. 113: 714-721.

Masala, G.; Porcu, R.; Madau, L.; Tanda, A.; Ibba, B.; Satta, G. and Tola, S. (2003): "Survey of ovine and caprine toxoplasmosis by IFAT and PCR assays in Sardinia, Italy. " Vet. Parasitol. 117, 15-21.

Mele, A.; Paterson, P.J.; Prentice, H.G.; Leoni, P. and Kibbler, C.C. (2002): "Toxoplasmosis in bone marrow transplantation: a report of two cases and systematic review of the literature." Bone Marrow Transplant. 29: 691-698.

Montoya, J.G. and Liesenfeld, O. (2004): "Toxoplasmosis," Lancet, 363 (9425): 19651976.

Murphy, M.A.; Shariflou, M.R. and Moran, C. (2002): "High quality genomic DNA extraction from large milk samples," J. Dairy Res. 69 (4): 645-649.

Pappas, G.; Roussos, N. and Falagas, M.E. (2009): "Toxoplasmosis snapshots: global status of Toxoplasma gondii seroprevalence and implications for pregnancy and congenital toxoplasmosis." Int. J. Parasitol. 39 (12): 1385-1394.

Pepin, M.; Russo, P. and Pardon, P. (1997): "Public health hazards from small ruminant meat products in Europe." Scientific and Technical Review of the Office International des Epizooties 16, 415-425.

Pettersen, E.K. (1984): "Transmission of toxoplasmosis via milk from lactating mice." Acta Pathologica Microbiologica Scandinavica Series B: Microbiology 92 (1-6): 175-176.

Petersen, E.; Pollak A. and Reiter-Owona, I. (2001): "Recent trends in research on congenital toxoplasmosis.” Int. J. Parasitol. 31: 115-144.

Powell, C.C.; Brewer, M. and Lappin, M.R. (2001): "Detection of Toxoplasma gondii in the milk of experimentally infected lactating cats." Vet. Parasitol. 102 (1-2): 29-33.

Prelezov, P.; Koinarski V. and Georgieva, D. (2008): "Seroprevalence of Toxoplasma gondii infection among sheep and goats in the Stara Zagora region." Bulgarian J. Vet. Med. 11 (2): 113-119.

Psifidi, A.; Dovas, C.I. and Banos, G. (2010): "A comparison of six methods for genomic DNA extraction suitable for PCR-based genotyping applications using ovine milk samples." Mol. Cell. Probes 24 (2): 93-98.

Ragozo, A.M.; Pena, H.F.; Yai, L.E.; Su, C. and Gennari, S.M. (2010): "Genetic diversity among Toxoplasma gondii isolates of small ruminants from Brazil: novel genotypes revealed." Vet. Parasitol. 170 (3-4): 307-312.

Räisänen, S.A. (1978): "The importance of trophozoites in transmission of toxoplasmosis: survival and pathogenity of Toxoplasma gondii trophozoites in liquid media." Med Hypotheses Jul-Aug; 4(4): 367-375.

Reischl, U.; Bretagne, S.; Kruger, D.; Ernault, P. and Costa, J.M. (2003): "Comparison of two DNA targets for the diagnosis of Toxoplasmosis by real-time PCR using fluorescence resonance energy transfer hybridization probes." BMC Infect. Dis. 3: 7.

Riemann, H.P.; Meyer, M.E.; Theis, J.H.; Kelso, G. and Behymer, D.E. (1975): "Toxoplasmosis in an infant fed unpasteurized goat milk." J. Pediatr. 87(4): 573-576.

Sacks, J.J.; Roberto, R.R. and Brooks, N.F. (1982): "Toxoplasmosis infection associated with raw goat's milk," J. Am. Med. Assoc. 8; 248: (14) 1728-1732.

Schalm, O.W.; Carroll, E.J. and Jain, N.C. (1971): "Number and types of somatic cells in normal and mastitic milk." In: Schalm, O. W., E. J., Caroll, and N. C., Jain (eds), Bovine mastitis, $1^{\text {st }}$ ed. pp.: 94- 127, Lea and Febiger, Philadelphia.

Schares, G.; Barwald, A.; Staubach, C.; Wurm, R.; Rauser, M.; Conraths, F.J. and Schroeder, C. (2004): "Adaptation of a commercial ELISA for the detection of antibodies against Neospora caninum in bovine milk." Vet. Parasitol. 120, 55-63.

Schurmann, D.; Bergmann, F.; Albrecht, H.; Padberg, J.; Wunsche, T.; Grunewald, T.; Schurmann, M.; Grobusch, M.; Vallee, M.; Ruf, B. and Suttorp, N. (2002): "Effectiveness of twice-weekly pyrimethamine-sulfadoxine as primary prophylaxis of Pneumocystis carinii pneumonia and toxoplasmic encephalitis in patients with advanced HIV infection." Eur. J. Clin. Microbiol. Infect. Dis. 21: 353-361.

Sharif, M.; Gholami, S.; Ziaei, H.; Daryani, A. and Laktarashi, B. (2007): "Seroprevalence of Toxoplasma gondii in cattle, sheep and goats slaughtered for food in Mazandaran province, Iran, during 2005." Vet. J. 174: 422-424.

Skinner, L.J.; Timperley, A.C.; Wightman, D.; Chatterton, J.M. and Ho-Yen, D.O. (1990): "Simultaneous diagnosis of toxoplasmosis in goats and goat owner's family," Scandinavian J. Infect. Diseases 22 (3): 359-361.

Smith, J.E. and Reduck, N.R. (2000): "Toxoplasma gondii Strain Variation and Pathogenicity. In: Microbial Foodborne Diseases: Mechanisms of Pathogenesis and Toxin Synthesis." Cary, J.W., J.E. Linz and B. Bhatnaga (Eds.) Technnomic Publishing, Lancaster.

Spišák, F.; Turčeková, L.; Reiterová, K.; Špilovská, S. and Dubinský, P. (2010): "Prevalence estimation and genotypization of Toxoplasma gondii in goats." Biologia 65(4): 670-674.

S.P.S.S. "Statistical Package for Social Sciences" (2007): "SPSS, version 16, Inc., Chicago, IL." 
Syamala, K.; Devada, K. and Pillai, K.M. (2008): "Diagnosis of caprine toxoplasmosis by Latex agglutination test" J. Vet. Anim. Sci. 39: 53-54.

Suzuki, Y. (2000): "Host resistance in the brain against Toxoplasma gondii." J. Infect. Diseases 185: 359-361.

Tavassoli, M.; Esmaeilnejad, B.; Malekifard, F.; Soleimanzadeh, A. and Dilmaghani, $M$. (2013): "Detection of Toxoplasma gondii DNA in sheep and goat milk in Northwest of Iran by PCR-RFLP." Jundishapur J. Microbiol. 6(10): e8201.
Tenter, A.M. (2009): "Toxoplasma gondii in animals used for human consumption," Memórias do Instituto Oswaldo Cruz 104 (2): 364-369.

Tenter, A.M.; Heckeroth, A.R. and Weiss, L.M. (2000): "Toxoplasma gondii: From animals to human." Int. J. Parasitol. 30(12-13): 12171258.

Walsh, C.P.; Hammond, S.E.; Zajac, A.M. and Lindsay, D.S. (1999): "Survival of Toxoplasma gondii tachyzoites in goat milk: potential source of human toxoplasmosis." J. Eukaryotic Microbiol. 46 (5): 73-74.

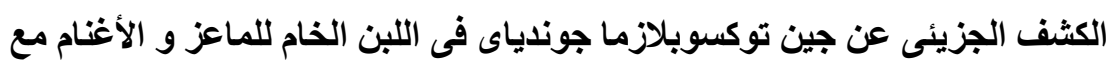

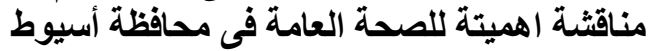 \\ أنسي أديب صادق ، زينب محمد عبل الحميل ، هلى محمد محمد قراعه}

أجريت هذه الدراسة لتحديد نسبة الاصابه بطفيل التوكسوبلازما ومدى انتشاره فى عينات الألبان الخام للأغنام و الماعز فى محافظة

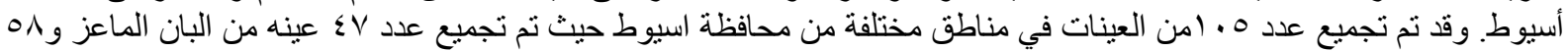

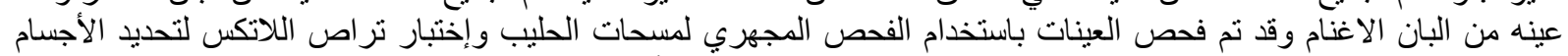

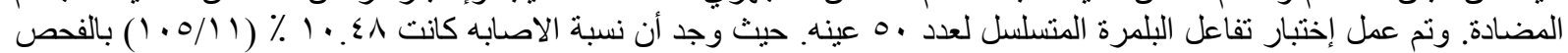

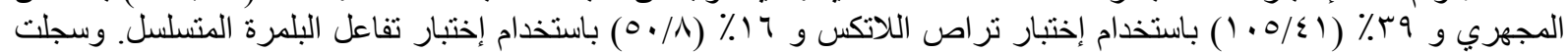

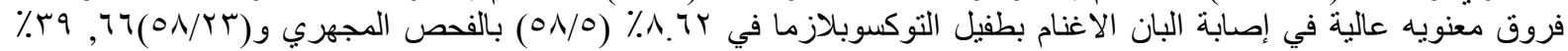

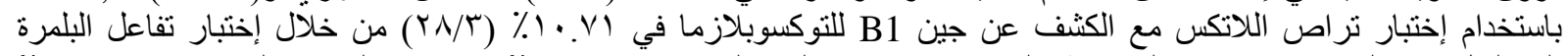

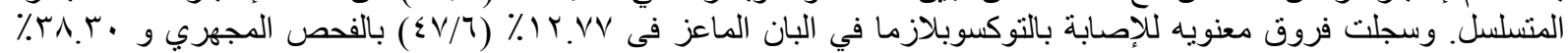

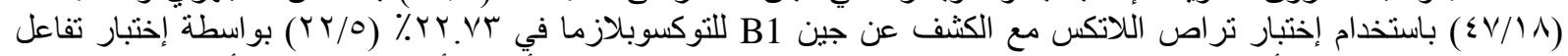

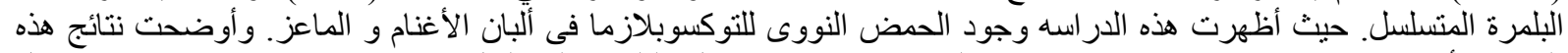

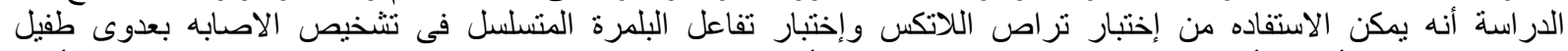

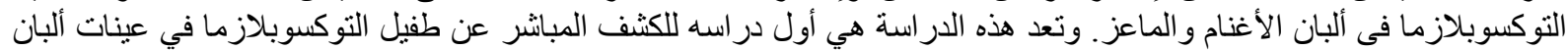

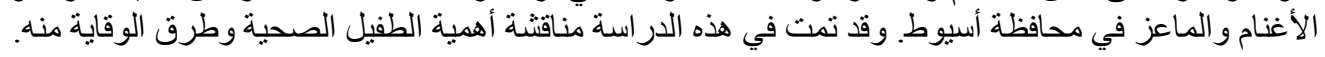

